\title{
A NOTE ON THE RECENTLY DISCOVERED GANESA IMAGE \\ FROM PALEMBANG, SUMATRA
}

Robert L. Brown

In a recent issue of Indonesia E. Edwards McK innon published a stone Ganesa found at Jalan Mayor Ruslan, Palembang in 1983 (figs. 1 and 2).1 He suggested a probable 12th-13th century date for the Ganesa and noted the statue's excellent condition. 2 In my opinion, Mckinnon's dating is too late and a 7 th or 8 th century date is more 1 ikely. 3 This earlier dating would place the Ganesa among the earliest images found at Palembang, and in fact in Sumatra. It would also mean that the Ganesa is one of the very few, if not the only, Hindu image from the Palembang area with such an early date, as the other earl iest known material from the region is Buddhist.

My 8th-century dating for the Ganesa is based on comparisons with Indian images, one of the closest comparisons being with the 7th-century Ganesa from the Bala-Brahma temple at Alampur (fig. 3 ). It is frequently as difficult to date Ganesa images in India as it is in Southeast Asia: the body type is usually determined by unchanging lconographic rather than stylistic considerations, and the elephant heads often vary radically, even within the same area and period. The Alampur Ganesa is, however, part of a set of saptamatrka that al lows us considerable additional comparative material. Dr. Katherine Harper Lorenzana, who is preparing a detailed study of saptamatrka, suggests an early 7 th century date for the Alampur matrkas and the Ganesa, because she believes they relate most closely to the Ellora Cave 21 and 14 sets of the latter half of the 6 th century. 4

In comparing the $A l a m p u r$ and Palembang Ganesas we can note the general similarities of body proportion and relative head size. Both gods wear their hair piled in a jatamukuta that sits well back from their foreheads. The attributes they hold are the same. They each hold a rosary (aksamala) in their upper right hand and an axe (parasu) in their left. Not only are the general size and shape of these attributes the same (compare particularly the almost identical construction of the axes), but the way they are held with the bent central fingers is also similar.

1. E. Edwards McKinnon, "Early Polities in Southern Sumatra: Some Preliminary Observations Based on Archaeological Evidence," Indonesia 40 (October 1985): Plate 9. I want to thank Dr. McKinnon for information regarding the Ganesa and for the photographs published here as figs. 1 and 2.

2. Ibid., p. 20.

3. Dr. Mckinnon in a personal letter says that an earlier date for the Ganesa could be indeed a possibility.

4. I want to thank Dr. Lorenzana for discussing the dating of the Bala-Brahma Ganesa with me. 


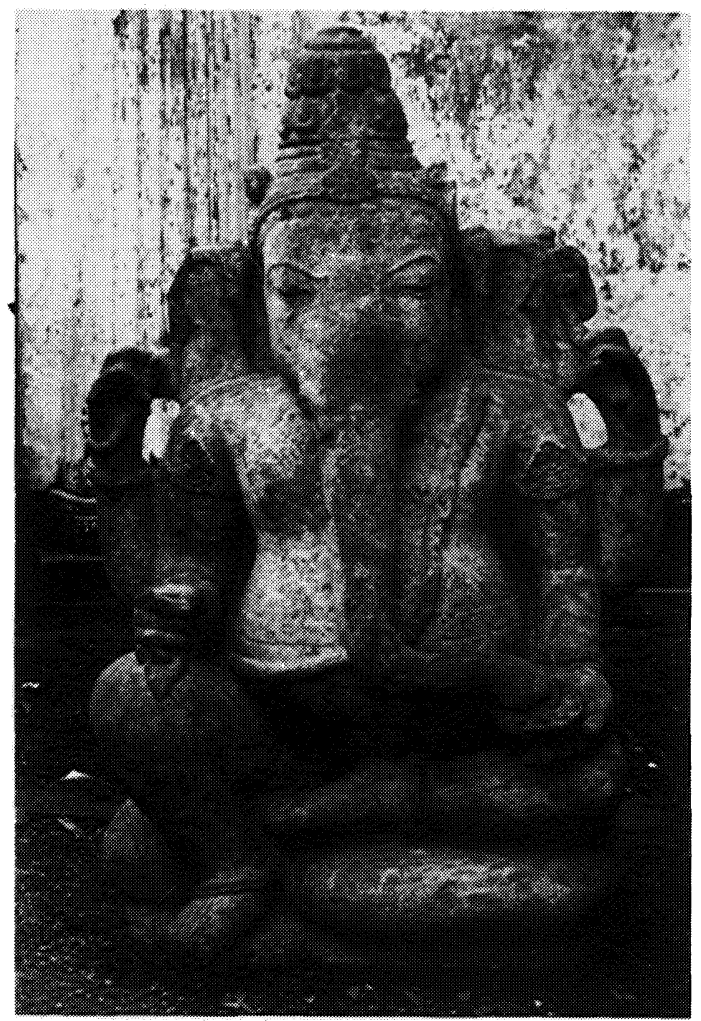

Fig. 1. Ganesa. Jalan Mahyor Ruslan, Paiembang, Sumatra. 7th-8th century. Stone. (Photo: Dr. E. Edwards McKinnon)

Fig. 2. Ganesa. Jalan Mahyor Ruslan, Paiembang, Sumatra. 7th-8th century. Stone. (Photo: Dr. E. Edwards Mckinnon)

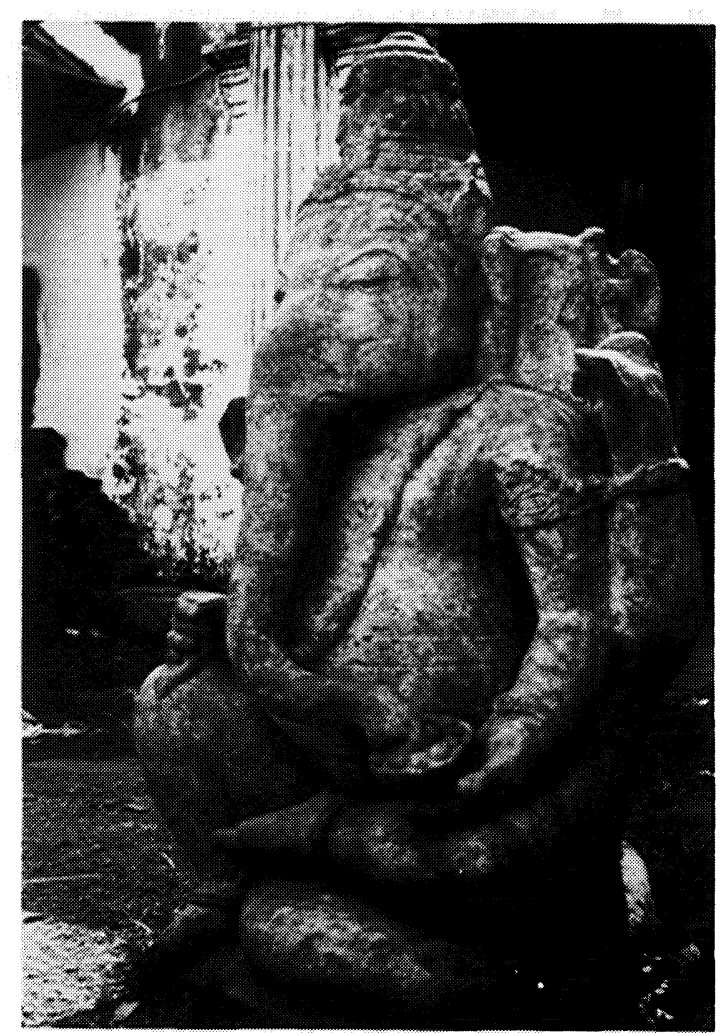




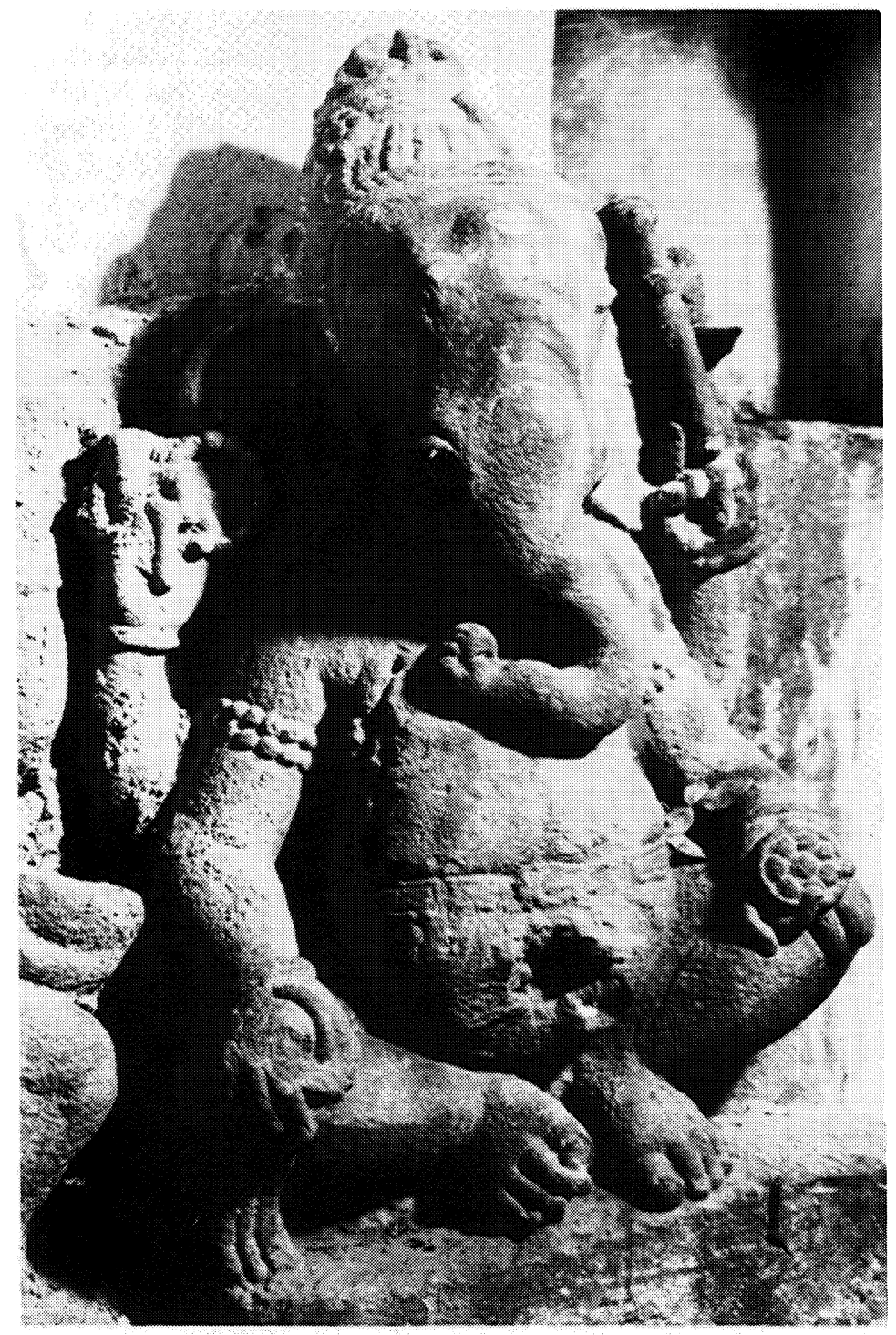

Fig. 3. Ganesa. Bala-Brahma Temple, Alampur, India. Early 7 th century. Stone. (Photo: Archaeological Survey of India) 
The modaka bow 1 held in the lower left hand of the two images is particularly telling. Appearing like a cut fruit with its seeds revealed, the Alampur modaka bowl is unusual in Indian art. The Palembang Ganesa's bowl closely reflects this Alanmpur attribute type. Furthermore, as a general rule, Southeast Asian Ganesas hold empty modaka bowls.

The final attributes, those held in the lower right hand, cannot be identified with certainty for either image. It is clear, however, that they are not tusks. That of the Alampur Ganesa could perhaps be a cloth. Ganesas from other Calukyan sites, such as Badami and Aihole, hold a variety of attributes in their lower right hands that often cannot be easlly identified: they sometimes appear to be money bags, garlands, vegetables (radishes?), or pieces of cloth. Judging from the photograph, the Palembang Ganesa's attribute may be broken on top. Nevertheless, it shares with the Alampur attribute a pliable quality not out of character with Calukyan prototypes.

If we were to broaden the comparison to other Calukyan art we would find additional similarities with the Palembang Ganesa. For our present purposes, however, the point is that the Palembang image must be close in date to the Alampur Ganesa, and it could not be more than a century later. In my opinion, the Palembang Ganesa is so completely Indian in style, iconography, and general feel that its importation from India must be considered a possibility. Initially arguing against this possibility is the image's size, approximately $180 \mathrm{~cm}$ high, larger, I think, than any other Indian image found elsewhere in Southeast Asia. The immigration of Indian artists to Southeast Asia is, of course, a different matter.

Could the Ganesa have been made locally? Other monumental stone sculpture has been found in the Palembang area, as McKinnon points out in his article. 5 Three of these are large inscribed steles that, as with the elegant Sabokingking stone with its naga heads, are sophisticated 7 ithic achievements. The Sabokingking stone argues for a local (or at least Sumatran) manufacture, as its unique form does not occur elsewhere in Southeast Asia. The Palembang inscription, along with four others from Southern Sumatra, give us both a time frame (682$686 \mathrm{AD}$ ) and $\mathrm{place}$ name (Srivijaya) for their manufacture. Their dates would, apparently, fit well with the Palembang Ganesa.

The Bukit Seguntang Buddha at over $360 \mathrm{~cm}$ is the largest stone sculpture from the Palembang area; Nik Hassan Shuhaimi has suggested that it dates to the late 7th-early 8th century.6 A second large stone image ( $\mathrm{H}: 172 \mathrm{~cm})$ from Palembang is a four-armed Avalokitesvara, 7 which could also, in my opinion, date to the 7th-8th centuries. Both images are, I think, decidedly Southeast Asian products, but Shuhaiml has proposed influence from Pala-period Eastern

5. Mckinnon, "Early Polities in Southern Sumatra," passim. F. M. Schnitger's 1937 monograph The Archaeology of Hindoo Sumatra (Leiden: Brili) still remains the standard discussion of the Palembang finds.

6. Nik Hassan Shuhaimi, "The Bukit Seguntang Buddha: A Reconsideration of Its Date," Journal of the Malaysian Branch of the Royal Asiatic Society 52, 2 (1979): 33-40. A good illustration is published in Bennet Bronson and Jan Wisseman, "Palembang as SrTvijaya: The Lateness of Early Cities in Southern Southeast As1a," Asian Perspectives 19, no. 2 (1976): Plate III.

7. For an illustration see McKinnon, "Early Polities in Southern Sumatra," Plate 8. 
India for the Buddha, 8 while Sinhalese influence is usually mentioned for the bodhisattva.9 Can we now propose yet a third monumental image from Palembang, and a Hindu one at that, of the same time-period and with Calukyan influence?

One possible explanation for the diverse character of these sculptures would be that all three images were imported from different areas. This is in 1 ine with Bennet Bronson's and Jan Wisseman's redeposition theory, in which they speculate that "the 7th century inscriptions and the 6th-10th century statues . . - are present [in Palembang] because they were brought in from somewhere else during the 14th-17th centuries."10 Bronson and Wisseman were at the time attempting to reconcile the early date of the inscriptions and sculpture with what they believed was a total lack of physical evidence for the occupation of the site before around the 14th century. Mckinnon's notice of late first millennium Chinese potsherds from Palembangll and the 1984 discovery of an extensive ancient habitation area west of modern Palembangl2 may revise Bronson's and Wisseman's conclusions as to how early there were settlements in this area, but even if evidence surfaces that these existed from the 7 th century on, we are still left with the odd stylistic mix of artistic objects from the site, and, unless considerably more sculpture is discovered, 13 with the puzzle of why so few objects, including several important statues which imply sophisticated workshops, have been found.

Finally, if the Palembang Ganesa was imported, could it have come from somewhere other than India? If this were so, the possible alternatives would be Sri Lanka or, more likely, elsewhere in Southeast Asia. Briefly, Sinhalese Ganesas tend to be later and follow Tamil (primarily Chola) styles. In Southeast Asia, one might look to Malaysia and Southern Thalland or Java. A number of Ganesa images are known from the Malay and Thai Peninsula that date to the 8 th century. 14 These are, however, modest images that show 7 ittle relation to the Palembang Ganesa. Likewise the Ganesa images from Java appear not to provide a likely source. The earliest Javanese Ganesas may be those from Dieng, which

8. I am not prepared to accept completely Shuhaimi's arguments for stylistic influences on the Buddha. His tortuous discussion relies completely on analysis of the Buddha's robe. He does not mention the head at all which, although damaged, does not appear to me to be Pala but closer to Sinhalese or South Indian images.

9. McKinnon, "Early Polities in Southern Sumatra," p. 13.

10. Bronson and Wisseman, "Palembang as Srtvijaya," p. 233.

11. E. Edwards McKinnon, "A Note on the Discovery of Spur-Marked Yueh-Type Sherds at Bukit Seguntang Palembang," Journal of the Malaysian Branch of the Royal Asiatic Society 52, 2 (1979): 41-47.

12. Mckinnon, "Early Polities in Southern Sumatra," pp. 15-17. This site, called Karanganyar, is also discussed by 0 . W. Wolters in "Restudying Some Chinese Writings on Srivijaya," Indonesia 42 (October 1986): 1-41.

13. The discovery of the Ganesa makes this now an actual possibility.

14. See, for example, Piriya Krairiksh, Art in Peninsula Thailand Prior to the Fourteenth Century A.D. (Bangkok: The Fine Arts Department [1980]), Plate 16, and Chirasa Khochachiwa, "The 01dest Ganesa Sculpture in Thailand," The Journal of Silpakorn University (1986), illustration on p. 82 (text in Thai). 
date to around the 8 th century. 15 While they are not, in fact, without similarities to Calukyan images, they are already Javanese in style, with such characteristics as the seated position in which the soles of the feet press together before the body. By the 9 th century Javanese Ganesas have a highly distinctive style that does not at all relate to the Palembang Ganesa.16

If the Palembang Ganesa were imported, therefore, India remains the most 1 ikely source. Another alternative exists, however: that the image was in fact carved in Sumatra by an Indian or Indian-trained artist. To prove this using art historical analysis is, obviously, difficult.17 The assumption might be that the object would necessarily display some non-Indian characteristics. Indeed, the Indian art historian might note that it is unusual for Indian Ganesas to have the elongated trunk, the human eyes with their raised eyebrows, or the two small skulls in the headdress. As I sald above, however, the variety among Indian Ganesas must give one pause in being categorical about such specific characteristics. The question of provenance for the Ganesa as well as for the other Palembang stone sculptures may be most amenable to a technical solution. A relatively simple microscopic cross-sectional analysis of the stone, which requires a very small sample, would immediately tell if the sculptures are from different stone sources. If samples were obtained from Sumatra's apparently restricted stone sources as well, very specific answers could be formulated. Such an analysis has been carried out by Richard Newman for areas of India, 18 but it is particulariy appropriate for Sumatra with its limited quarries and number of sculptures.

In summary, two possibilities present themselves for the Palembang Ganesa: either it was imported from India or it was made outside of India, probabiy in Sumatra, by an Indian or Indian-trained artist. In either case, the image probably dates to the 8th century and thus adds a new early and significant Hindu face to Sumatran Srtvijaya.19

15. See Alice Getty, Ganesa: A Monograph on the Elephant-Faced God (Oxford: At the Clarendon Press, 1936), Plate $30 \mathrm{c}$ and $d$.

16. For a discussion of Southeast Asian Ganesa images see my "Ganesa in Southeast Asian Art: Indian Connections and Indigenous Developments" forthcoming in a volume on Ganesa throughout Asia edited by A. K. Narain.

17. The most consistent attempt at such an analysis for Southeast Asian art is A. B. Griswold, "Imported Images and the Nature of Copying in the Art of Siam," in Essays offered to G. H. Luce by His Colleagues and Friends in Honour of His Seventy-Fifth Birthday, 2 vols., ed. Ba Shin et al. (Ascona: Artibus Asiae, 1966) 2:37-73. While his conclusions appear to be widely accepted, I feel many of them should best be considered tentative.

18. Richard Newman, The Stone Sculpture of India: A Study of the Material used by Indian Sculptors from $\mathrm{ca}$. 2nd Century B.C. to the 16 th Century (Cambridge: Harvard University Art Museums, 1984).

19. Dr. McKinnon in his letter tells me that a second but damaged Ganesa was found at Palembang about a century ago. He also says he is writing an article on Sivaite remains from Sumatra which will, certainiy, be very helpful in assessing the Ganesa discussed here. 